\title{
Comparative Analysis of Maternal and Fetal Outcomes of Pregnancies Complicated and Not Complicated with Hyperemesis Gravidarum Necessitating Hospitalization
}

\author{
Hastanede Yatmayı Gerektiren Hiperemezis Gravidarum ile Komplike \\ Olan ve Komplike Olmayan Gebeliklerin Maternal ve Fetal Sonuçlarının \\ Karşılaştırmalı Analizi
}

\section{Taner GUNAY $\odot$, Abdulkadir TURGUT $\odot$, Reyhan AYAZ BILIR $\odot$, Meryem HOCAOGLU $\odot$, Ergul DEMIRCIVI BOR $\odot$}

Ethics Committee Approval: This study was approved by the Istanbul Medeniyet University, Goztepe Training and Research Hospital, Clinical Studies Ethic Committee, 9 January 2019, 2019/0002. Conflict of interest: The authors declare that they have no conflict of interest.

Funding: None.

Informed Consent: Not Applicable.
Cite as: Gunay T, Turgut A, Ayaz Bilir R Hocaoglu M, Demircivi Bor E. Comparative analysis of maternal and fetal outcomes of pregnancies complicated and not complicated with hyperemesis gravidarum necessitating hospitalization. Medeniyet Med J. 2020;35:8-14.

\begin{abstract}
Objective: To compare maternal and fetal outcomes of pregnancies complicated and not complicated with hyperemesis gravidarum (HG) necessitating hospitalization.

Method: A total of 386 women with singleton deliveries between March 2015 and January 2018 were included in this retrospective single-center study. Of 386 women, 186 women (mean $\pm S D$ age: $30.7 \pm 5.9$ years) who were hospitalized with HG within the first 20 weeks of gestation comprised the hyperemetic pregnancy group, while 200 women without HG during pregnancy served as a control group.

Results: No significant difference was noted between the HG and control groups in terms of maternal characteristics, gestational age (median 38.6 and 39.0 weeks, respectively), type of delivery (normal spontaneous delivery in $78.0 \%$ vs $80.0 \%$ ), fetal gender (female: $53.2 \%$ vs $48.5 \%$ ), birthweight (median $3250 \mathrm{~g}$ vs $3275 \mathrm{~g}$ ) and 5-min APGAR scores ( $\geq 7$ in $97.3 \%$ vs $97.5 \%$, respectively). Adverse pregnancy outcomes were also similar between groups including preterm birth (8.1\% vs $11.0 \%$, respectively), SGA (5.9\% vs 9.5\%), hypertensive disorder (5.4\% vs $7.5 \%)$, placental abruption $(1.1 \%$ vs $0.5 \%$,), stillbirth $(0.0 \%$ vs $0.5 \%)$ and GDM (3.8\%vs $2.5 \%)$. Weight loss during pregnancy was evident in $91.3 \%$ of women in the HG group, while none of women in the control group had weight loss during pregnancy $(p<0.001)$.

Conclusions: The findings of this study indicate that HG may not be related with adverse fetal and prenatal outcomes and this conclusion needs to be clarified with large-scale investigations.
\end{abstract}

Keywords: HG, fetal outcomes, maternal outcomes

Öz

Amaç: Hastaneye yatarak tedavi gerektiren hiperemezis gravidarum (HG) ile komplike gebelikler ile hiperemezis gravidarum görülmeyen gebeliklerin maternal ve fetal sonuçlarını karşılaştırmak.

Yöntem: Tek merkezde yapılan bu retrospektif çalışmaya 2015 Mart ile 2018 Ocak arasında

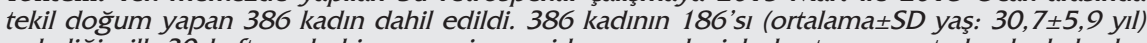
gebeliğin ilk 20 haftasında hiperemezis gravidarum nedeniyle hastaneye yatırılan kadınlardan oluşurken hiperemezis gravidarum görülmeyen 200 kadın kontrol grubu olarak oluşturdu. Bulgular: HG ve kontrol grupları arasında maternal özellikler, ve sırasıyla gebelik yaşı (ortalama 38,6 ve 39,0 hafta), doğum şekli (normal spontan doğum, \%78,0 ve \%80,0), fetal cinsiyet (kız, $\% 53,2$ ve \%4,5), doğum ağırlığı (ortalama $3250 \mathrm{~g}$ ve $3275 \mathrm{~g}$ ) ve $5 \mathrm{dk}$. 'lık APGAR skorları ( $\geq 7$, $\% 97,3$ ve \%97,5) farklılık görülmedi. Olumsuz gebelik sonuçları olarak değerlendirilen preterm doğum (\%8,1 ve \%11,0), SGA $(\% 5,9$ ve \%9,5), hipertansif hastalıklar (\%5.4 ve \%7.5), dekolman plasenta (\%1,1 ve \%0,5) ve GDM (\%3,8 ve \%2.5) görülme oranları da benzer bulundu. Gebelik sırasında kilo kaybı hiperemezis gravidarum grubundaki kadınların \%91,3 'ünde görülürken, kontrol grubundaki kadınların hiçbirinde gebelik sırasında kilo kaybı görülmedi $(p<0.001)$.

Sonuç: Bu çalışmanın bulguları, geniş ölçekli başka çalışmalarla doğrulanmak üzere, hiperemezis gravidarumun olumsuz fetal ve maternal komplikasyonlarla ilişkili olmayabileceğine işaret etmektedir.

Anahtar kelimeler: Hiperemezis gravidarum, fetal sonuç, maternal sonuç
Received: 1 January 2020 Accepted: 24 January 2020 Online First: 28 February 2020

Corresponding Author: T. Gunay ORCID: 0000-0002-3985-0702 Istanbul Medeniyet University, Goztepe Training and Research

Hospital, Department of Obstetrics and Gynecology, Istanbul, Turkey

$\checkmark$ tanergunay@hotmail.com

ORCID: 0000-0002-3156-2116

R. Ayaz Bilir

ORCID: 0000-0001-5261-1792

M. Hocaoglu

ORCID: 0000-0002-1832-9993

E. Demircivi Bor

ORCID: 0000-0002-4448-3863

Istanbul Medeniyet University

Goztepe Research and Training Hospital, Department of

Obstetrics and Gynecology, Istanbul, Turkey 
T. Gunay et al. Comparative Analysis of Maternal and Fetal Outcomes of Pregnancies Complicated and Not Complicated with Hyperemesis Gravidarum Necessitating Hospitalization

\section{INTRODUCTION}

HG, unlike the nausea and vomiting experienced by many women in early pregnancy, is a potentially life-threatening condition occurring in 0.3 to $3 \%$ of pregnancies ${ }^{1,2}$.

HG is a frequent reason for hospitalization among pregnant women, and is a disease for which the diagnosis is based on clinical judgment given the lack of well-defined diagnostic criteria ${ }^{2,3}$. Notably, the adverse impact of HG on pregnancy outcomes, particularly for the offspring, remains inconclusive in terms of the associated risk for low birthweight, preterm birth, small-for-gestationalage (SGA), stillbirth and abnormalities of placental conditions $^{2-8}$.

Therefore, there is a need for studies addressing the potential effect of HG on pregnancy outcomes via uniform diagnostic criteria and possible confounders $^{2,3}$.

This retrospective cohort study of singleton deliveries was therefore designed to comparatively evaluate the maternal and fetal outcomes of pregnancies complicated or uncomplicated with HG necessitating hospitalization.

\section{MATERIALS and METHODS}

\section{Study population}

This study approved by the Istanbul Medeniyet University, Goztepe Training and Research Hospital Clinical Studies Ethics Committee. A total of 386 women (median age 26 years, range, 17-39 years) with singleton deliveries between March 2015 and January 2018 were included in this retrospective single-center study. Of 386 women, 186 women (mean \pm SD age: $30.7 \pm 5.9$ years) who were hospitalized with HG within the first 20 weeks of gestation comprised the hyperemetic pregnancy group, while 200 women without HG during pregnancy served as a control group. HG was defined as long-lasting nausea and vomit- ing requiring antepartum hospitalizations for hyperemesis before the $20^{\text {th }}$ week of gestation. All pregnant women who were hospitalized in our center within the study period due to HG during the first 20 weeks of gestation were included in the study. Pregnant women with HG treated on an outpatient basis, those at $>20$ weeks of gestation and those who gave birth in other hospitals were excluded from the study.

\section{Study parameters}

Data on maternal characteristics (age, smoking status, parity, weight loss during pregnancy), delivery characteristics (gestational age, type of delivery), fetal characteristics (gender, birthweight, 5-min APGAR scores) and adverse pregnancy outcomes including preterm birth, small for gestational age (SGA), pregnancy-induced hypertensive disorder, placental abruption, stillbirth and gestational diabetes mellitus (GDM) were recorded in both the hyperemesis gravida and control groups.

Hypertensive disorders of pregnancy were classified according to the International Society for the study of Hypertension in Pregnancy (ISSHP) definitions?.

Preterm delivery was accepted as $<37$ gestationweek deliveries. Stillbirth was defined as birth of an infant with no signs of life at or after 24 weeks of gestation. SGA was defined as birth weight at a particular gestational age below the 10th percentile.

\section{Statistical analysis}

Statistical analysis was made using IBM SPSS Statistics for Windows, Version 25.0 software (IBM Corp., Armonk, NY, USA). Fisher's exact test, Pearson Chi-Square test and Fisher-FreemanHalton Test (Monte Carlo) were used to analyze categorical variables, while numerical data were analyzed using the Mann-Whitney U test. Data were expressed as mean (standard deviation; $\mathrm{SD})$, minimum-maximum, quartiles (Q1, Q3) and 
number (n) and percentage (\%) where appropriate. $p<0.05$ was considered statistically significant.

\section{RESULTS}

\section{Maternal characteristics}

No significant difference was noted between the HG and control groups in terms of maternal characteristics including age (median 26 years for each), percentages of nonsmokers $(94.6 \%$ and $95.0 \%$, respectively) and parity (57\% were nulliparous in each group) (Table 1).

Weight loss during pregnancy was evident in 91.3\% of women (up to $6.9 \mathrm{~kg}$ in $56.9 \%$ ) in the HG group, while none of women in the control group had weight loss during pregnancy ( $p<0.001$, Table 1$)$.

\section{Delivery characteristics}

No significant difference was noted between the HG and control groups in terms of delivery characteristics including gestational age (median 38.6 vs 39.0 weeks) and type of delivery (normal spontaneous delivery: $\mathbf{7 8 . 0} \%$ vs $\mathbf{8 0 . 0 \%}$ ) (Table 2 ).

\section{Fetal characteristics}

No significant difference was noted between the HG and control groups in terms of fetal characteristics including gender (female: $53.2 \%$ vs $48.5 \%$ ), birthweight (median $3250 \mathrm{~g}$ vs $3275 \mathrm{~g}$,), 5-min APGAR scores ( $\geq 7$ in $97.3 \%$ vs $97.5 \%$ ) (Table 2 ).

Table 1. Maternal characteristics in the study groups.

\begin{tabular}{|c|c|c|c|c|c|}
\hline & & Total $(n=386)$ & HG $(n=186)$ & Control $(n=200)$ & p value \\
\hline \multicolumn{6}{|l|}{ Maternal characteristics } \\
\hline Age (years), median (min/max) & & $26(17 / 39)$ & $26(18 / 39)$ & $26(17 / 36)$ & $0.743^{1}$ \\
\hline \multicolumn{6}{|l|}{ Smoking, n (\%) } \\
\hline No & & $366(94.8)$ & $176(94.6)$ & $190(95.0)$ & $0.999^{2}$ \\
\hline Yes & & $20(5.2)$ & $10(5.4)$ & $10(5.0)$ & \\
\hline \multicolumn{6}{|l|}{ Parity } \\
\hline Nulliparous & & $220(57.0)$ & $106(57.0)$ & $114(57.0)$ & \\
\hline \multirow[t]{3}{*}{ Multiparous } & & $166(43.0)$ & $80(43.0)$ & $86(43.0)$ & $0.999^{2}$ \\
\hline & Yes & $170(44.0)$ & $170(91.3)^{*}$ & $0(0.0)$ & \\
\hline & $<6.9 \mathrm{~kg}$ & $106(27.4)$ & $106(56.9)^{*}$ & $0(0.0)$ & \\
\hline \multirow[t]{3}{*}{ Weight loss during pregnancy, n (\%) } & $7-14.9 \mathrm{~kg}$ & $19(4.9)$ & $19(10.2)^{*}$ & $0(0.0)$ & $<0.001^{3}$ \\
\hline & $\geq 15.0 \mathrm{~kg}$ & $2(0.5)$ & $2(1.1)$ & $0(0.0)$ & \\
\hline & Missing & $43(11.1)$ & $43(23.1)$ & - & \\
\hline
\end{tabular}

${ }^{1}$ Mann Whitney U Test (Monte Carlo), ${ }^{2}$ Pearson Chi-Square Test (Exact), ${ }^{3}$ Fisher Freeman Halton Test (Monte Carlo) ${ }^{*} p<0.001$ compared to control group

Table 2. Delivery and fetal characteristics in the study groups.

\begin{tabular}{|c|c|c|c|c|}
\hline & Total $(n=386)$ & HG $(n=186)$ & Control $(n=200)$ & p value \\
\hline \multicolumn{5}{|l|}{ Delivery characteristics } \\
\hline $\begin{array}{l}\text { Gestational age (week), median (Q1/Q3) } \\
\text { Type of delivery, } \mathbf{n}(\%)\end{array}$ & $38.65(37.5 / 40)$ & $38.6(37.6 / 40)$ & $39(37.5 / 40.05)$ & $0.927^{1}$ \\
\hline $\mathrm{C} / \mathrm{S}$ & $81(21.0)$ & $41(22.0)$ & $40(20.0)$ & $0.708^{2}$ \\
\hline Normal spontaneous delivery & 305 (79.0) & $145(78.0)$ & $160(80.0)$ & \\
\hline \multicolumn{5}{|l|}{ Fetal characteristics } \\
\hline \multicolumn{5}{|l|}{ Fetal gender, n (\%) } \\
\hline Female & $196(50.8)$ & $99(53.2)$ & $97(48.5)$ & $0.361^{2}$ \\
\hline Male & $190(49.2)$ & $87(46.8)$ & $103(51.5)$ & \\
\hline $\begin{array}{l}\text { Fetal birthweight (gr), median (Q1/Q3) } \\
\text { 5-min APGAR, n (\%) }\end{array}$ & $3265(2870 / 3640)$ & $3250(2850 / 3610)$ & $3275(2915 / 3640)$ & $0.698^{1}$ \\
\hline$\geq 7$ & $376(97.4)$ & $181(97.3)$ & 195 (97.5) & $0.999^{3}$ \\
\hline$<7$ & $10(2.6)$ & $5(2.7)$ & $5(2.5)$ & \\
\hline
\end{tabular}

${ }^{1}$ Mann Whitney U Test(Monte Carlo), ${ }^{2}$ Pearson Chi-Square Test (Exact), ${ }^{3}$ Fisher Exact Test (Exact) 
T. Gunay et al. Comparative Analysis of Maternal and Fetal Outcomes of Pregnancies Complicated and Not Complicated with Hyperemesis Gravidarum Necessitating Hospitalization

Table 3. Adverse pregnancy outcomes in study groups.

\begin{tabular}{|c|c|c|c|c|}
\hline & Total $(n=386)$ & HG $(n=186)$ & Control $(n=200)$ & p value \\
\hline \multicolumn{5}{|c|}{ Adverse pregnancy outcomes, n (\%) } \\
\hline \multicolumn{5}{|c|}{ Preterm delivery } \\
\hline No & $349(90.4)$ & 171 (91.9) & $178(89.0)$ & \multirow[t]{2}{*}{0.388} \\
\hline Yes & $37(9.6)$ & $15(8.1)$ & $22(11.0)$ & \\
\hline \multicolumn{5}{|l|}{ SGA } \\
\hline No & $356(92.2)$ & $175(94.1)$ & $181(90.5)$ & \multirow[t]{2}{*}{0.253} \\
\hline Yes & $30(7.8)$ & $11(5.9)$ & $19(9.5)$ & \\
\hline \multicolumn{5}{|c|}{ Hypertensive disorder } \\
\hline No & $361(93.5)$ & $176(94.6)$ & $185(92.5)$ & \multirow[t]{2}{*}{0.417} \\
\hline Yes & $25(6.5)$ & $10(5.4)$ & $15(7.5)$ & \\
\hline \multicolumn{5}{|c|}{ Placental abruption } \\
\hline No & $383(99.2)$ & $184(98.9)$ & $199(99.5)$ & \multirow[t]{2}{*}{$\mathrm{N} / \mathrm{A}$} \\
\hline Yes & $3(0.8)$ & $2(1.1)$ & $1(0.5)$ & \\
\hline \multicolumn{5}{|c|}{ Stillbirth } \\
\hline No & 385 (99.7) & $186(100.0)$ & 199 (99.5) & \multirow[t]{2}{*}{ N/A } \\
\hline Yes & $1(0.3)$ & $0(0.0)$ & $1(0.5)$ & \\
\hline \multicolumn{5}{|c|}{ Gestational diabetes } \\
\hline No & 374 (96.9) & $179(96.2)$ & 195 (97.5) & \multirow[t]{2}{*}{0.564} \\
\hline Yes & $12(3.1)$ & $7(3.8)$ & $5(2.5)$ & \\
\hline
\end{tabular}

Pearson Chi-Square Test (Exact)

\section{Adverse pregnancy outcomes}

No significant difference was noted between the $\mathrm{HG}$ and control groups in terms of adverse pregnancy outcomes including rates for preterm birth (8.1\% vs $11.0 \%$,), SGA delivery (5.9\% vs $9.5 \%$,), hypertensive disorder (5.4\% vs $7.5 \%)$, placental abruption ( $1.1 \%$ vs $0.5 \%)$, stillbirth $(0.0 \%$ vs $0.5 \%$, ) and GDM (3.8\% vs $2.5 \%$ ) (Table 3 ).

Pregnancy-induced hypertensive disorder in the HG $(n=10)$ and control $(n=15)$ groups involved preeclampsia (in 5 and 7 cases, respectively), gestational hypertension (in 4 and 7 cases, respectively) and chronic hypertension with superimposed pre-eclampsia (1 case in each group).

\section{DISCUSSION}

The findings of this retrospective cohort study on women with singleton deliveries who experienced complicated or uncomplicated pregnancies with HG did not reveal any significant impact of HG on maternal and fetal outcomes in terms of fetal birthweight, 5-min APGAR scores, preterm birth, SGA, pregnancy-induced hypertensive disorder, placental abruption, stillbirth and GDM.
Similar to these findings, in a previous retrospective cohort study of fetal and maternal outcomes in pregnancies with or without HG from Turkey, any statistically significant differences were not reported between pregnancies with or without hyperemesis in terms of SGA birth, preterm birth, Apgar scores, fetal birth weight, gestational diabetes, pregnancy-induced hypertension, or fetal gender and type of delivery ${ }^{8}$. The authors of that study concluded that HG was not associated with adverse pregnancy outcomes ${ }^{8}$.

Likewise, in a Norwegian mother and infant cohort of 71,468 singleton pregnancies, no association of HG was reported with low birthweight, preterm birth, delivering SGA infant and 5-min Apgar scores, regardless of the maternal weight gain $(<7 \text { or } \geq 7 \mathrm{~kg})^{3}$.

The current study findings revealed similar risks for placental abruption and placental insufficiency disorders including gestational hypertension, pre-eclampsia and stillbirth in pregnancies complicated or uncomplicated with HG. This supports the data from a prospective cohort study of 2252 pregnant women, which indicated lack of any as- 
sociation of HG with placental insufficiency, poor neonatal outcomes and placental outcomes ${ }^{10}$.

However, although the current study findings support the view that HG requiring hospitalization was not associated with an increased risk for preterm birth, low birth weight or SGA ${ }^{3,8}$, it should be noted that there are conflicting data in the literature on fetal outcomes and placental conditions after in-utero exposure to maternal $\mathrm{HG}^{2}$.

In a population-based retrospective Norwegian cohort study of 156,000 singleton pregnancies, hyperemetic pregnancies were reported to be associated with an increased risk of low birth weight, SGA, preterm delivery, 5-min Apgar scores <7 compared to pregnancies without hyperemesis, but only for women gaining less than $7 \mathrm{~kg}$ during pregnancy 4 . The authors indicated that the adverse fetal outcomes associated with hyperemesis were related to and mostly limited to poor maternal weight gain ${ }^{4}$.

In a Swedish cohort study, HG in the first trimester was reported to be associated with an increased risk of subsequent complications of pre-eclampsia, and preterm delivery with pre-eclampsia, in addition to placental abruption and delivering an SGA infant ${ }^{11}$.

Findings from a Dutch historical cohort study of 1.2 million singleton births revealed an association of HG with an increased risk for preterm delivery but not for SGA or low birth weight ${ }^{12}$. An American cohort study of 520,000 live births reported that HG was associated with a higher likelihood of delivering a low birth weight and SGA infant ${ }^{6}$.

In a meta-analysis of studies on $\mathrm{HG}$ and pregnancy outcomes, it was reported that HG was associated with a $30 \%$ increase in risk for preterm birth and SGA, and a $40 \%$ increase in risk for low birth weight infants ${ }^{13}$.

In fact, low maternal gestational weight gain, re- gardless of maternal hyperemesis status, has been considered to be associated with an increased risk of preterm birth, low birth weight and intrauterine growth retardation ${ }^{14,15}$. This emphasizes the association between $\mathrm{HG}$ and adverse pregnancy outcomes to be related to poor maternal weight gain rather than the direct effect of $\mathrm{HG}^{3,4,7}$, along with the greater risk for growth retardation and fetal anomalies in HG cases with weight loss > 5\% of the pre-pregnancy weight ${ }^{7}$.

Given that weight loss was evident $(<6.9 \mathrm{~kg}$ in $56.9 \%$ and $7-14.9 \mathrm{~kg}$ in $10.2 \%$ of the pregnants) in $91.3 \%$ of the women with HG in the current study cohort, the lack of association of HG or concomitant weight loss with adverse pregnancy outcomes supports the view that with good antenatal care and management of women hospitalized with HG, the risk of adverse pregnancy outcomes is likely to be diminished ${ }^{3}$.

Nonetheless, whether or not HG was associated with negative short-term consequences, the possibility of long-term consequences related to fetal undernutrition during first trimester has also been suggested, including an increased risk for cardiovascular disease, diabetes and schizophrenia in later life $\mathrm{j}^{3,16,17}$.

Moreover, in a population-based cohort study in 8211850 pregnancies, presence of HG was reported to be associated with increased risk of anemia, preeclampsia, eclampsia, venous thromboembolism in addition to increased risk of cesarean, induced or preterm/very preterm delivery, low birth weight or SGA babies and post-natal neonatal intensive care stay ${ }^{18}$.

Although the exact etiology of HG remains unknown, it is considered to be a multifactorial disease $^{2}$. Age group of 20-24 years, nulliparity and underweight were reported to be the factors associated with severe hyperemesis gravidarum ${ }^{19}$. The characteristics of women with hyperemetic pregnancies in the current study cohort support 
T. Gunay et al. Comparative Analysis of Maternal and Fetal Outcomes of Pregnancies Complicated and Not Complicated with Hyperemesis Gravidarum Necessitating Hospitalization

the higher likelihood of younger (vs. older) maternal age, nonsmoker (vs. active smoker) status and primiparity (vs. multiparity) in pregnancies complicated by $\mathrm{HG}^{2,20,21}$.

While adverse pregnancy outcomes of HG are conflicting and the current study findings revealed no association of the condition with an increased risk of fetal or maternal outcomes compared to the control pregnancies, it should be noted that HG has been associated with a significant psychosocial burden in women together with an adverse impact on daily activities ${ }^{22}$ in addition to increased risk of low quality of life negatively affecting the acceptance of pregnancy and the role of motherhood $^{23}$. This seems notable given the reported lack of support from healthcare professionals and suboptimal management of women with $\mathrm{HG}^{22}$.

The retrospective single center design seems to be the major limitation to the current study, which prevents establishing the temporality between cause and effect as well as generalizing our findings to overall $\mathrm{HG}$ population.

\section{CONCLUSION}

These findings of a retrospective cohort of women with singleton deliveries who experienced complicated or uncomplicated pregnancies with HG, seem to indicate that HG may not be related with adverse fetal and prenatal outcomes and this conclusion needs to be clarified with large-scale investigations addressing not only short-term consequences but also possible long-term risks of $\mathrm{HG}$ on the offspring as well as the perspectives of women suffering from $\mathrm{HG}$.

\section{REFERENCES}

1. Verberg MF, Gillott DJ, Al-Fardan N, Grudzinskas JG. Hyperemesis gravidarum, a literature review. Hum Reprod Update. 2005;11(5):527-39. [CrossRef]

2. London V, Grube S, Sherer DM, Abulafia O. Hyperemesis Gravidarum: A Review of Recent Literature. Pharmacology. 2017;100(3-4):161-71. [CrossRef]

3. Vikanes $\AA$ V, Støer NC, Magnus P, Grjibovski AM. Hyper- emesis gravidarum and pregnancy outcomes in the Norwegian Mother and Child Cohort - a cohort study. BMC Pregnancy Childbirth. 2013;13:169. [CrossRef]

4. Dodds L, Fell DB, Joseph KS, Allen VM, Butler B. Outcomes of pregnancies complicated by hyperemesis gravidarum. Obstet Gynecol. 2006;107(2 Pt 1):285-92. [CrossRef]

5. Paauw JD, Bierling S, Cook CR, Davis AT. Hyperemesis gravidarum and fetal outcome. JPEN J Parenter Enteral Nutr. 2005;29(2):93-6. [CrossRef]

6. Bailit JL. Hyperemesis gravidarium: epidemiologic findings from a large cohort. Am J Obstet Gynecol. 2005;193:811-4. [CrossRef]

7. Gross S, Librach C, Cecutti A. Maternal weight loss associated with Hyperemesis gravidarium: a predictor of fetal outcome. Am J Obstet Gynecol. 1989;160:906-9. [CrossRef]

8. Kuru O, Sen S, Akbayır O, et al. Outcomes of pregnancies complicated by Hyperemesis gravidarium. Arch Gynecol Obstet. 2012;285:1517-21. [CrossRef]

9. Brown MA, Magee LA, Kenny LC, et al. International Society for the Study of Hypertension in Pregnancy (ISSHP). Hypertensive Disorders of Pregnancy: ISSHP Classification, Diagnosis, and Management Recommendations for International Practice. Hypertension. 2018;72:24-43. [CrossRef]

10. Koudijs HM, Savitri AI, Browne JL, et al. Hyperemesis gravidarium and placental dysfunction disorders. BMC Pregnancy Childbirth. 2016;16:374. [CrossRef]

11. Bolin M, Åkerud H, Cnattingius S, Stephansson O, Wikström AK. Hyperemesis gravidarium and risks of placental dysfunction disorders: a population-based cohort study. BJOG. 2013;120:541-7. [CrossRef]

12. Roseboom TJ, Ravelli AC, van der Post JA, Painter RC. Maternal characteristics largely explain poor pregnancy outcome after Hyperemesis gravidarium. Eur J Obstet Gynecol Reprod Biol. 2011;156:56-9. [CrossRef]

13. Veenendaal MV, van Abeelen AF, Painter RC, van der Post JA, Roseboom TJ. Consequences of HG for offspring: a systematic review and meta-analysis. BJOG. 2011;118:1302-13. [CrossRef]

14. Han Z, Lutsiv O, Mulla S, Rosen A, Beyene J, McDonald SD; Knowledge Synthesis Group. Low gestational weight gain and the risk of preterm birth and low birthweight: a systematic review and meta-analyses. Acta Obstet Gynecol Scand. 2011;90:93-954. [CrossRef]

15. McDonald SD, Han Z, Mulla S, Beyene J; Knowledge Synthesis Group. Overweight and obesity in mothers and risk of preterm birth and low birth weight infants: systematic review and meta-analyses. BMJ. 2010;341:c3428. [CrossRef]

16. Roseboom TJ, Painter RC, van Abeelen AFM, Veenendaal MVE, de Rooij SR. Hungry in the womb: what are the consequences? Lessons from the Dutch famine. Maturitas. 2011;70:141-5. [CrossRef]

17. Rapoport JL, Giedd JN, Gogtay N. Neurodevelopmental model of schizophrenia: update 2012. Mol Psychiatry. 2012;17:1228-38. [CrossRef]

18. Fiaschi L, Nelson-Piercy C, Gibson J, Szatkowski L, Tata LJ. Adverse Maternal and Birth Outcomes in Women Admitted to Hospital for Hyperemesis Gravidarum: a Population-Based Cohort Study. Paediatr Perinat Epidemiol. 2018;32:40-51. [CrossRef]

19. Thakur M, Gautam J, Dangal G. Severity of Hyperemesis 
Gravidarum and Associated Maternal factors. J Nepal Health Res Counc. 2019;17:293-6. [CrossRef]

20. American College of Obstetricians and Gynecologists. Practice Bulletin No. 153: Nausea and vomiting of pregnancy. Obstet Gynecol 2015;126:12-24. [CrossRef]

21. Boelig RC, Barton SJ, Saccone G, Kelly AJ, Edwards SJ, Berghella V. Interventions for treating HG. Cochrane Database Syst Rev. 2016;5: CD010607. [CrossRef]
22. Havnen GC, Truong MB, Do MH, Heitmann K, Holst L, Nordeng $\mathrm{H}$. Women's perspectives on the management and consequences of HG - a descriptive interview study. Scand J Prim Health Care. 2019;37:30-40. [CrossRef]

23. Türkmen $H$. The effect of hyperemesis gravidarum on prenatal adaptation and quality of life: a prospective case-control study. J Psychosom Obstet Gynaecol. 2019;25:1-8. [CrossRef] 